\title{
7. Romanska språk nyligen, nu och i framtiden
}

\author{
Björn Larsson
}

\subsection{Då}

Jag tar mig friheten att inleda med några ord om min personliga drygt fyrtioåriga universitetshistoria. På fler än ett sätt illustrerar den nämligen den utveckling som skett under åren, både inom mitt eget ämne, franska, och inom de romanska språken.

Jag satte min fot - som väl rätteligen borde vara i plural - på Romanska institutionen (hädanefter RI) i Lund för första gången januari 1974, då det var dags att tentera några av de A-delkurser som jag hade läst in per korrespondens på Hermods, dåtidens internetkurser. Därefter fortsatte jag med B-kursen på distans, det vill säga medan jag bodde i Paris och låtsades vara författare. Först hösten 1975 slog jag mig ner i Lund och läste kandidatkursen på vanligt vis, med föreläsningar och studentliv. Det var väl ungefär då som jag på allvar började bli intresserad av franska som ämne; dittills hade det mest varit fråga om ett sätt att tjäna levebrödet med studielån för att kunna odla mina författardrömmar.

Till forskarutbildningen antogs jag våren 1976. Vad jag inte visste då var att det hade hängt på ett hår att jag faktiskt kunde bli antagen; bara något år tidigare hade man gjort om studieplanen för forskarutbildningen och tagit bort kravet på kunskaper i latin för särskild behörighet, vilket redan i sig var ett uttryck för en utveckling av ämnet, vars orsaker man kan spekulera om. Jag, som i gymnasiet hade gått naturvetenskaplig linje, var därför den förste doktorand vid institutionen som antogs utan att ha läst latin.

Att jag skulle skriva om ett litterärt ämne var ganska självklart, men inte heller det hade varit möjligt bara några få år dessförinnan. Den första avhandlingen i ett litterärt ämne vid RI i Lund hade lagts fram bara ett år tidigare, 1975, och då i spanska; det var Brita Brodin som skrev om Cortázar och på det kontot senare blev lektor i spanska. Den första avhandlingen i fransk litteratur dröjde ytterligare några år, till 1979; det var Sigbrit Swahn som la fram sin studie om Proust dans la recherche littéraire, som också gjor- 
de henne till dubbeldoktor eftersom hon redan tidigare hade doktorerat $\mathrm{i}$ litteraturvetenskap, vilket delvis också förklarade varför hon blev den första att doktorera i franska med litterär inriktning. Flera skulle dock följa.

För RI:s del representerade litteraturens intåg som forskningsämne en ganska stor förändring. Tidigare, under professor Alf Lombards ledning, låg tyngdpunkten nästan uteslutande på filologi, även om modern lingvistik började göra sig gällande mot slutet av Lombards långa professorstid.

Den som öppnade dörren för en litterär forskarutbildning och forskning var Lombards efterträdare, Östen Södergård, vars professur benämndes "professor i romanska språk, särskilt franska". Något större motstånd bland övriga kolleger, samtliga språkvetenskapliga lektorer och docenter, fanns inte, vad jag kunnat förstå, mot utvidgningen av ämnet mot litteratur. Det är inte mycket till förklaring att säga att "tiden var mogen" för en förändring, men vad som gjorde förändringen möjlig eller önskad är svårt att säga; det får kanske bli en fråga att besvara för kommande vetenskapshistoriker.

Vad som däremot är klart är att den litteraturvetenskapliga forskningen led av barnsjukdomar. Östen Södergård var filolog och självlärd i litteraturvetenskap; övriga docenter var språkvetare även de, vilket gjorde att de litterära doktoranderna ibland tvingades söka specialisthandledning utanför institutionen. Att tillsätta en professor i fransk litteratur var det aldrig tal om ... och det kom heller aldrig på tal, förrän helt nyligen, då fakulteten $\mathrm{i}$ humaniora och teologi beslutade att sätta upp en professor i fransk litteratur på den så kallade grundbemanningslistan över professurer i olika ämnen. Undertecknad, som haft ansvaret för den litterära forskarutbildningen och forskningen de senaste drygt tjugo åren, är professor i franska, inte i fransk litteratur, och har såväl språk- som litteraturvetenskaplig kompetens. Faktum är att det i landet, före befordringsreformen, bara fanns en enda professur i fransk litteratur, närmare bestämt vid Uppsala universitet.

Situationen i spanska och italienska var delvis en annan än i franska; båda hade länge få studenter i jämförelse med franska och undervisningen sköttes av vardera två lärare, en utländsk lektor och en svensk, varav ingen var docent. Det dröjde därför ända till 1992, det vill säga 17 år, innan det var dags för nästa avhandling i spanska efter Brita Brodins; den här gången var det Ingrid Hermerén i spansk språkvetenskap. Två år senare, 1994, var det dags för institutionens andra avhandling någonsin i italienska då Sven 
Ekblad disputerade på sin studie av Umberto Ecos Il nome della rosa. Båda dessa avhandlingar hade handletts av Östen Södergårds efterträdare, professor Lars Lindvall, som behärskade fler än ett romanskt språk.

Samtidigt var Lars Lindvall av den åsikten att institutioner i främmande språk inte skulle syssla med litteraturvetenskap; han gjorde - förtjänstfullt ett undantag för Sven Ekblad, som var anställd som adjunkt i italienska vid institutionen, och uppmuntrade de som redan var antagna, bland dem jag själv. Om sin principiella skepsis, inte till litteratur väl att märka, som han gärna läste, utan till litteraturvetenskap på språkinstitutioner, var han inte ensam i Lund; då tyska erbjöds att inrätta en professur i tysk litteratur tackade den dåvarande ämnesföreträdaren blankt nej. Å andra sidan var bilden inte helt klar vad beträffar fördelningen mellan språk- och litteraturvetenskap på de dåvarande språkinstitutionerna; tack vare professor Claes Schaar hade litteratur exempelvis en stark ställning på den engelska institutionen.

Nästa stora förändring i romanska språk i Lund, precis som på andra universitet i Sverige, var att spanska drog till sig allt fler studenter, samtidigt som franskans dittills dominerande ställning minskade. I samband med att Inger Enkvist tillträdde som lektor i spanska i Lund gjordes en radikal omläggning av ämnet; man satsade uteslutande på litteraturvetenskaplig forskning och gav litteraturen en mycket större plats i grundutbildningen. Det dröjde faktiskt ända till för några år sedan innan en lektor med språkvetenskaplig inriktning anställdes, och de få avhandlingar som producerades i spansk språkvetenskap kom att handledas av Paul Touati, som var professor i fransk lingvistik, men med grundutbildning i spanska. I italienska rådde det motsatta förhållandet: forskning bedrevs uteslutande i språkvetenskap och det var först runt 2010 som en lektor med litteraturvetenskaplig kompetens anställdes ... på $25 \%$.

När Lars Lindvall återvände till Göteborg tillträdde Suzanne Schlyter den professur som fortfarande benämndes "romanska språk, särskilt franska". Suzanne Schlyter utnämning gjorde att den språkvetenskapliga forskningen återigen ändrade inriktning, med större inslag av allmänlingvistik och med en specialisering mot språkinlärning, som fortsatt fram till idag. I samma veva, utan strategiska diskussioner eller beslut, upplöstes det forskarseminarium som hade varit gemensamt både för hela RI och för språk- och litteraturvetenskap. Spanska startade sin egen seminarieverksamhet 
med inriktning mot spansk litteratur. Den franska litteraturen fick ett eget seminarium under min ledning, medan Suzanne Schlyter ledde ett forskarseminarium i språkvetenskap för franska, italienska och rumänska. En annan förändring var att språkvetarna i de fyra romanska språken inledde ett mer utbrett samarbete med andra lingvister, både på språkinstitutionerna och på institutionen för lingvistik, med gemensamma seminarier. Något liknande skedde aldrig, vare sig i fransk eller spansk litteratur; delvis, men inte enbart, därför att så få litteraturvetare (läs en eller två) behärskade något av de romanska språken.

Nästa betydelsefulla steg i de romanska språkens utveckling var inte heller det resultatet av ämnesmässiga diskussioner eller strategiska beslut, utan en konsekvens av den så kallade befordringsreformen. För RI i Lunds del innebar det att man från att ha haft en enda ämnesansvarig professor i romanska språk med särskild inriktning mot ett enskilt språk, så kunde man inom några år ståta med inte mindre än sex professorer, varav en i italiensk språkvetenskap, en i spansk litteratur, och fyra i franska, varav tre i språkvetenskap och en - undertecknad - i både språk- och litteraturvetenskap.

Nästa större förändring kom i samband med inrättandet av Språk- och litteraturcentrum, SOL kallat, år 2005, då RI upphörde att existera som en självständig enhet. Och även om de romanska språken, plus grekiska och latin, samlades i ett gemensamt så kallat kollegium, så hade de hädanefter egna kostnadsställen och behandlades ekonomiskt var för sig. Detta innebar bland annat att de enskilda ämnena skulle klara sig ekonomiskt var för sig; om något av de romanska ämnena behövde stöd, exempelvis vid sviktande studentunderlag, så var det inte längre fråga om ett slags solidaritet mellan de romanska språken, utan med SOL som helhet.

En annan förändring som påverkade de romanska språkens utveckling, återigen utan att våra ämnen kunde göra vare sig till eller ifrån, var riksdagsbeslutet att enbart anta doktorander som hade finansiering i form av doktorandtjänster. Antalet doktorander minskade på kort tid drastiskt, samtidigt som konkurrensen om de få tjänsterna skärptes. Exempelvis dröjde det över åtta år innan en ny doktorand i fransk litteratur kunde antas, trots att sju doktorander hade disputerat i ämnet under åren dessförinnan. Det minskade antalet doktorander gjorde det också svårare att upprätthålla en livaktig seminarieverksamhet. 
Nämnas bör också att fakulteten beslutade att det bara fick inrättas två masterprogram på SOL, samtidigt som den tidigare magisterkursen lades ned, just den kurs som hade fungerat som rekryteringsbas och lockbete för studenter som var intresserade av forskarutbildningen. På SOL inrättades följaktligen två masterprogram, ett i litteraturvetenskap, "Litteratur, kultur och media”, med inriktningar mot olika språk, och ett i språkvetenskap, dito. Eftersom nära hälften av kurserna gavs på engelska blev det nu ännu svårare att locka studenter till masterprogrammen inom de främmande språken, engelska undantaget, i all synnerhet då chanserna att få en doktorandtjänst efter fullfört masterprogram var och är försvinnande få.

Med större eller mindre variationer skedde en liknande utveckling som den ovan beskrivna på andra romanska institutioner i landet, samtidigt som flera högskolor startade kurser i franska och spanska. När jag började mina studier kunde man bara läsa franska i Lund, Göteborg, Stockholm och Uppsala. Enstaka kurser gavs då och då på olika högskolor, som köpte in lärartjänster och examinationsrättigheter från de stora universiteten. Så skedde exempelvis i Kalmar, Växjö och Halmstad. Numera ges kurser i franska dessutom i Umeå, Växjö, Linköping, samt, "nätbaserat", på Högskolan Dalarna. Andra har startat, men lagt ner: Södertörn, Halmstad, Örebro och Kalmar, bland annat.

\section{$7.2 \mathrm{Nu}$}

Det som slagit mig när jag tänkt tillbaka på de romanska språkens utveckling i Lund och runt om i landet är hur litet den har styrts av egna initiativ, pedagogiskt eller forskningsmässigt. Med få undantag har viktiga förändringar varit betingade av externa faktorer. ${ }^{62}$ Men om man med två ord skulle beskriva vad som hänt med de romanska språken sedan åttiotalet så måste det bli "separation" och "specialisering", som ju delvis är betingade av varandra. Dels språken emellan, dels inom språken, i huvudsak mellan språk- och litteraturvetenskap, men också, inte att förglömma, inom dessa båda huvudområden.

62 Ett mer anekdotiskt exempel på hur externa faktorer kan påverka ett ämnes utveckling kan hämtas från litteraturvetenskap i Lund. Som bekant har ämnet litteraturvetenskap historiskt stått närmare historisk-filosofiska ämnen än språken och var i Lund en del av den historisk-filosofiska fakulteten. Men på grund av en infekterad professorstillsättning i historia hade ledningen för litteraturvetenskap inget att invända emot att ämnet blev en del av SOL. Man lämnade alltså sin traditionella fakultetstillhörighet utan att diskutera vilka konsekvenser detta skulle kunna få för ämnet. 
Vad specialiseringen beträffar skiljer sig inte romanska språk nämnvärt från andra universitetsämnen. Teori-, metod- och kunskapsmängden inom i stort sett alla ämnen har ökat exponentiellt, så att det blir omöjligt att hålla sig a jour med forskningen om man inte specialiserar sig. För ett antal år sedan skrev jag en bok om adjektivepitetets betydelse och placering i modern franska. Före mig hade det publicerats cirka tio tusen sidor om samma ämne. Om man lägger till det som hade skrivits om frågan i övriga romanska språk och det som har skrivits sedan dess, så kanske man hamnar på det tredubbla. I dag skulle det vara svårt att utge sig för att vara spetsforskare i kvalificerad mening till och med inom ett så avgränsat fält som adjektivet $\mathrm{i}$ franskan, för att inte tala om adjektivet i romanska språk.

När jag inledde mina studier i franska hade den redan nämnde professorn i romanska språk, Alf Lombard, strax dessförinnan gått i pension. Lombard var polyglott: förutom att han talade franska, spanska och rumänska flytande, kunde han klara sig rätt bra på italienska. Han behärskade - förstås - klassisk grekiska och latin, samt kunde engelska och tyska. Anekdoterna om honom var många. Det berättades med förtjusning att när någon från utlandet frågade honom vilket språk de skulle tala, så brukade Lombard svara: "vi tar det som ni kan bäst".

På den tiden, när forskningen i romanska språk framför allt var inriktad på filologi och fornspråk, så var det så att säga fortfarande möjligt att verkligen vara professor i romanska språk, utan inriktning mot något enstaka av språken. Men det krävde förstås att man behärskade väl fler än ett språk, vilket fick till följd att just professuren i romanska språk betraktades som särskilt "svår", med åtföljande akademisk prestige. Det visste Lombard, som förde sig fram med en viss emfas.

En dag, på ett möte i fakultetsrådet, tröttnade en av Lombards kolleger på hans framfusighet och lär ha yttrat: ”Det är väl ingen konst att kunna så många språk ... när man inte har något att säga på dem.”

Om denna anekdot är helt och hållet sann vågar jag inte säga, men det är ändå betecknande att den berättades. För den fångar på sätt och vis de romanska språkens dilemma, både tillsammans och var för sig.

Att lära sig två eller tre romanska språk tillräckligt väl för att kunna undervisa i dem på lägre nivåer är kanske ingen oöverkomlig uppgift, i synnerhet om man redan har ett romanskt språk som modersmål, och "bara" 
ska lära sig tillräckligt med svenska för att kunna fungera i universitetsmiljön. Man kan också, vilket gäller i mitt eget fall och för en del andra kolleger i landet, lära sig ytterligare ett eller två romanska språk, utöver huvudspråket, för att kunna vara sakkunnig, delta i betygskommittéer eller handleda doktorander ... i Lund har specialister på franska handlett doktorander i spanska. Men i synnerhet när det gäller handledning är det sällan en idealisk lösning. Själv skulle jag heller aldrig ta på mig ett uppdrag som opponent inom ett annat romanskt språk, lika litet som jag skulle kunna undervisa i spanska eller italienska, ens på A- eller B-kurser. Att bedriva forskning av hög kvalitet är uteslutet. Man skulle kunna sammanfatta dilemmat så, att ju fler romanska språk man lär sig att behärska på hög nivå, desto mindre tid har man att tillägna sig något att säga om de olika språken och dess litteratur, eller, för att återknyta till anekdoten om Lombard: ju fler språk man lär sig, desto mindre har man att säga på dem om dem, inklusive om dess litteratur.

Dilemmat blir inte mindre av att man, för att kunna bedriva forskning på hög nivå, måste specialisera sig ytterligare, typiskt mellan språk- och litteraturvetenskap. På den tiden då danska romanister var världsledande, med namn som Blinkenberg, Togeby, Nøjgaard och Pedersen, betraktades det som naturligt att man forskade i både språk- och litteraturvetenskap och kunde begå sig på fler än ett romanskt språk. Den store grammatikern Knut Togeby recenserade fransk litteratur i dagspressen. Morten Nøjgaard, som är känd för sina teoretiska och metodiska verk om litteraturvetenskap, skrev också två tegelstenar om adverb. John Pedersen, som var specialist på sjuttonhundratalets litteratur, skrev också en universitetsgrammatik tillsammans med kolleger. Under ett samtal med just John Pedersen för några år sedan benämnde han sig själv och sina ämnesöverskridande kolleger i högre ålder som de "sista dinosaurerna”, en utdöende art ... till vilken jag numera måste räkna mig själv.

Noteras bör dock att romanistik, internationellt sett, till allra största delen har bedrivits i form av språkvetenskap, i synnerhet diakront. Om man öppnar något översiktsverk över de romanska språkens utveckling, exempelvis C. Camproux Les langues romanes (1974), så lyser litteraturen med sin frånvaro. Inom komparativ litteratur, som utomlands i högre grad än i Sverige är ett vedertaget begrepp och ämne, har "romansk litteratur" 
aldrig studerats som en enhet. $\AA$ ena sidan har studiet av den nationella litteraturen varit allt dominerande inom de romanskspråkiga länderna - i Frankrike är studier i "franska" liktydigt med studier i den franska, eventuellt franskpråkiga, litteraturen; man kan bli docteur ès lettres utan att någonsin tvingats läsa Dante, Cervantes eller Shakespeare! Å den andra finns det litteraturhistoriskt inga bevis på att författare som skriver på romanska språk företrädesvis har hämtat inspiration från varandras litteraturer; enstaka författare, ja, Stendhal och Italien exempelvis (även om Stendhals absoluta favorit var Shakespeare), Vargas Llosa och Flaubert, Calvino och Oulipo, Flaubert och Don Quijote, men Balzac hämtade inspiration från Walter Scott, Sartre från bland annat Faulkner och dos Passos, Romain Gary från Tolstoy. Med andra ord har begreppet "romanistik" en stark slagsida mot språk, på bekostnad av dess litteratur, vilket inte gör det enklare att se hur "romanska språk" skulle kunna bli en ämnesmässig enhet. Men inte ens när det gäller språket i sig är de olika romanska språken likvärdiga: portugisiska - trots att det talas av hundratals miljoner i Brasilien - och rumänska har fört en ganska undanskymd tillvaro, för att inte tala om rätoromanska eller occitanska!

Värt att notera är också, att då romanska institutioner, både i Sverige och utomlands, har skilts åt, så har det funnits en tendens att franska och italienska gått åt ett håll, och spanska/hispanistik åt ett annat. Vad detta beror på är svårt att säga, men möjligen är det ett tecken på att Frankrike och Italien, historiskt och kulturellt, står varandra närmare än Frankrike/ Italien och Spanien.

Den fråga som inställer sig är förstås hur vi som undervisar och forskar i något av de romanska språken ska förhålla oss såväl till romanistik som till specialiseringen mot språk eller litteratur inom varje språk. Ska vi bejaka utvecklingen eller göra motstånd mot den? Har utvecklingen gått för långt? Eller för att ställa frågan mer konstruktivt: vad är det vi som lärare och forskare inom de romanska språken har - eller skulle kunna ha - gemensamt, oberoende av om vi forskar och undervisar i språk, litteratur eller kultur och samhälle?

För det första är det naturligtvis ingenting som hindrar att vi uppmuntrar studenter att ta en kandidatexamen i två romanska språk eller att, som i Uppsala, inrätta ett masterprogram i romanska språk. Frågan är emellertid 
vilka argument man skulle kunna förelägga den presumtive studenten för att välja det alternativet. Jag har svårt att föreställa mig att dagens student, med undantag av någon enstaka som är språkhistoriskt intresserad, skulle låta sig övertygas av det faktum att romanska språk tillhör samma språkfamilj, har ett gemensamt ursprung i (vulgär)latinet och att de historiskt, och i viss mån ännu, har hängt ihop på universitet. Lärartjänster i skolan med kombinationer av romanska språk, främst franska och spanska, finns, men är tämligen sällsynta, liksom på universitetet. Man kan också, förstås, tänka sig att studenten satsar på en karriär som tolk eller översättare, specialiserad i två eller flera romanska språk. Men hur motiverar man de studenter som främst är intresserade av litteratur snarare än av språket i sig?

Mot resonemang som dessa skulle man kunna invända - vilket jag gärna gör - att universitetet inte bara eller ens företrädesvis är en yrkesskola; mot begreppet "anställningsbarhet" kan man på goda grunder ställa en tanke om "användbarhet". Att man skulle avkräva universitetet och dess lärare en synsk förmåga att förutsäga arbetsmarknadens specifika behov åratal i förväg faller på sin egen orimlighet. Vissa tecken tyder emellertid på att engelskans roll som globaliseringens lingua franca kommer att minska i framtiden till förmån för en rad olika språk som varje nation behöver behärska, bland dem de romanska. Brexit har för övrigt redan lett till att röster höjts i Europaparlementet att ersätta engelskan som ett av två officiella och juridiskt bindande språk. Man kan alltså mycket väl föreställa sig en utveckling mot en situation där varje europeiskt land måste se till att ha god kompetens inom en rad olika språk, i stället för att "nöja sig" med engelska, vilket även skulle gynna de romanska.

I grund och botten, vill jag dock hävda, är benämningen "romanska språk" en fråga om identitet, som inte går att besvara med vetenskapliga eller rationella argument enbart. Det finns inget vetenskapligt svar på frågan om varför det är särskilt intressant att studera universum, ett författarskap, adjektivets placering eller ett eller flera romanska språk. Om jag personligen gärna uppmuntrar studenter att studera ett eller flera romanska språk så är det därför att jag menar att det finns mycket värdefullt - kulturellt, intellektuellt och litterärt - att hämta i de romanska länderna; kunskaper och konstnärliga uttryck som inte är tillgängliga på engelska enbart. Men inte nog med det: genom franska har man tillgång till vetenskap, filosofi 
och litteratur från hela världen. Ser man på procentdelen översättningar av den totala bokutgivningen så ligger den i Frankrike på runt 30 \%, medan motsvarande siffra i England och USA är runt $5 \%$ !

Men samtidigt måste man vara realist, tyvärr. Redan på masternivå och i ännu högre grad inom forskarutbildningen blir kraven på spetskunskaper samt metodisk och teoretisk färdighet så höga att det knappast låter sig göras att fortsätta vara romanist i någon kvalificerad mening, förutom möjligen om man är språkhistoriker eller filolog i den klassiska bemärkelsen. Det är trots allt betecknande att så få avhandlingar i Sverige på de romanska institutionerna, även på den tiden då tjänster och institutioner hade romanska i sina beteckningar, faktiskt har varit tydligt romanska i sina ämnesval. En genomgång jag gjorde av alla de skrifter som publicerats i romanska skriftserier i Göteborg, Lund, Stockholm och Uppsala gav vid handen att endast 3 av totalt 328 otvetydigt kunde sägas vara inom romanistik.

\subsection{I framtiden}

Hur ska vi då förhålla oss till relationen mellan språk- och litteraturvetenskap inom våra respektive "romanska" ämnen? Specialiseringen har redan nu gått så långt att det är tveksamt om romanska språk- och litteraturvetare kritiskt kan granska och tillgodogöra sig varandras forskning i någon kvalificerad mening. Man kan alltså på fullt allvar ställa frågan om ett enskilt språk, romanskt eller ej, fortfarande ska betraktas som ett sammanhållet forskningsämne, eller om det är fråga om två separata, på samma sätt som nordiska språk/svenska är skilt från litteraturvetenskap.

Jag vet att somliga kolleger inte ser något problem med en sådan utveckling, medan andra beklagar den. Jag hör till de senare, eftersom jag menar att språk- och litteraturvetare har mycket att vinna på att kunna dela sina kunskaper och forskningsresultat, i synnerhet i främmande språk (men inte bara!). Jag skulle till och med vilja hävda att det är just därför att språk och litteratur normalt ingår som naturliga delar av språkämnena som språk- och litteraturvetare i främmande språk har ett särskilt uppdrag att identifiera och undersöka gemensamma frågeställningar för att därigenom både bidra till nya kunskaper och till att sätta gängse teorier och metoder på prov. Men vinsterna kommer inte per automatik; det kräver att det finns någon form av grundläggande konsensus inte bara om vad forskningen i främmande 
språk bör prioritera och ägna sig åt, utan också vad forskning i språk och litteratur har för vetenskapsteoretisk grund. Eller, mer korrekt uttryckt, vad språk respektive litteratur $\ddot{a} r$ !

\section{es}

Den moderna lingvistiken uppstod som bekant i början av nittonhundratalet i Freges, Saussures och Wittgensteins efterföljd då språklig mening skildes från referenten och språket började behandlas som ett självständigt system av strukturer och regelbundenheter. Från att ha varit i stort sett uteslutande diakronisk blev forskning om språk huvudsakligen synkronisk. Samtidigt skedde en förskjutning i fokus: man började på ett helt annat sätt än tidigare intressera sig för de delar av språket som uppvisade en hög grad av systematik, främst fonetik, fonologi och syntax, medan de mer "röriga" och föränderliga delarna, främst deskriptiv semantik och dess utlöpare lexikografi fick stryka på foten.

Utvecklingen bort från mening mot former och strukturer förstärktes ytterligare när Chomsky formulerade sin generativa teori utifrån grundantagandet att det fanns en underliggande struktur som var gemensam för alla språk. Från att ha varit fransk, tysk eller engelsk blev lingvistiken "allmän". Den här gången var det beskrivningen av de enskilda språken som fick sig en törn till förmån för sökandet efter de strukturer som språken hypotetiskt delade.

Det är obestridligt att den moderna lingvistiken, som egen vetenskap, ledde till flera viktiga insikter och nya kunskaper. Men sökandet efter språkets universella djupstruktur uppenbarade samtidigt - och litet paradoxalt - hur ofantligt komplext språket var, vilket väl var ett av skälen till att lingvistiken så att säga tog slut vid punkt, det vill säga att den till långt största delen studerade satser och deras syntax. Man observerade visserligen, i viss mån, förbindelser mellan enskilda satser, men längre texter, bland dem litterära verk, lyste med sin frånvaro; de ingick helt enkelt inte som en naturlig del av den korpus som lingvistiken skulle studera.

Vad som däremot inte förändrades under ganska lång tid var att lingvister i gemen fortsatte att företrädesvis hämta sina exempel från skriftspråket, och i synnerhet från litteraturen. Det var trots allt ganska bekvämt att sitta vid sitt skrivbord och excerpera i stället för att ge sig ut på fältet och samla 
in korpusar av talat språk. Efter hand började emellertid även icke-litterära texter, som tidningstexter, göra sitt intåg i exempelsamlingarna.

Vad som orsakade nästa paradigmskifte är svårt att avgöra, men under slutet av nittonhundratalet utvecklade det sig bland lingvister en föreställning om att skriftspråket, och i synnerhet det litterära språket, var ett särskilt språk, som inte hade så mycket att göra med det "naturliga" språket. Man började sålunda i allt högre grad studera det talade språket utifrån en - spekulativ hypotes om att det var där som språkets "riktiga" natur uppenbarade sig. I bakgrunden spökade förmodligen Chomskys tanke om att huvudmålet för lingvistiken inte var att beskriva enskilda språk, utan de universella strukturer som underpinned alla språk. Men även i studiet av enskilda språk flyttades fokus från la parole, det vill säga det verkliga språkbruket, till la langue, det vill säga de strukturer, regelbundenheter och mönster som karakteriserade språket "i sig", oberoende av dess varianter. I stället för stora och representativa korpusar av språk i bruk räckte det i fortsättningen med att konsultera ett begränsat antal informanter för att avgöra vad som var grammatiskt riktigt eller acceptabelt, ibland även - trots den kritik som tidigare hade riktats mot intuitionen som akribi - vad ett ord eller en sats betydde.

Oberoende av orsakerna kan man nog säga att pendeln på relativt kort tid svängde över från skriftspråket till det talade språket. Detta innebar att många lingvister slutade inte bara att studera det litterära språket, om ett sådant funnes, utan också att läsa litteratur som ett normalt led i det vetenskapliga arbetet. Därför uppstod här, men implicit, ett slags konflikt mellan språkvetare och litteraturvetare i främmande språk, som tog sig uttryck i diskussioner om vilken roll litterära texter skulle ha, inte bara inom forskningen, utan också på grundutbildningen. Tidigare hade det varit självklart att studenterna skulle läsa litterära texter, helst också bra texter, för att lära sig grammatik och vokabulär; nu problematiserades denna mer språkpedagogiska användning av romaner, poesi och teater, samtidigt som litteraturvetarna ställde krav om att de litterära texterna också behandlades som litteratur. På RI i Lund har förts många och långa diskussioner om valet av litterära texter på grundutbildningen, för att de både skulle vara ett stöd för språkinlärningen och vara litterärt intressanta eller viktiga. Specialiseringen mellan de två grenarna har också lett till diskussioner om vem som kan och bör undervisa i vad. Tidigare var det självklart att en svensk 
lektor skulle kunna undervisa i alla moment och delkurser, med eventuellt undantag av muntlig språkfärdighet, upp till och med kandidatnivå. Det är det inte längre. Att uppsatshandledningen på kandidatnivån bör skötas av specialister är väl klart, men för övrigt måste som jag ser det en lektors kompetens, med rätt förberedelser förstås, räcka till att undervisa i samtliga delkurser.

\section{$\cos$}

En liknande utveckling som den inom lingvistiken har intressant nog gjort sig gällande även inom litteraturvetenskap - vilket skulle tyda på att båda vetenskaperna är "offer" för djupare och bredare intellektuella strömningar. Från att ha varit inriktad på litteraturens förhållande till verkligheten, i synnerhet i ett historiskt perspektiv, kom litteraturen alltmer, med de ryska formalisterna och Roman Jakobsen som inspiration, att behandlas som ett självständigt system, som skulle förstås och tolkas på sina egna villkor. The text and nothing but the text blev både den anglosaxiska och den kontinentala litteraturteorins slagord. Barthes skrev sin berömda text om The death of the author, som var ett slags fadersmord på den tidigare förhärskande tanken att det var författaren, inklusive hennes eller hans livssituation och historiska kontext, som var nyckeln till en adekvat tolkning av texten. Strukturalismen, som med Genette och Todorov i spetsen kom att dominera litteraturvetenskapen under många år, övertog från de ryska formalisterna begreppet "litteraritet", det vill säga definitionsmässigt den eller de textelement, grammatiska och/eller semantiska, som skulle vara typiska och unika för litterära texter. Man talade om den litterära textens "autonomi" och benämnde det litterära verket en "artefakt". Prinsar och prinsessor i sagorna försvann och ersattes i Propps och Greimas efterföljd med "aktanter" och "adjuvanter". I USA gick det så långt att literary theory blev ett eget ämne, som man kunde studera och ta betyg i utan att behöva läsa en enda roman eller dikt.

Man kan för övrigt notera att det finns fler exempel på en parallell utveckling av de två vetenskaperna. Det teoriutkast om språkhandlingar som filosofen Austin la fram i How to do things with words fördes vidare inom lingvistiken som talaktsteori och pragmatik. Inom litteraturteorin upptäckte man ungefär samtidigt, för övrigt av en romanist, Hans Robert Jauss, och en 
anglicist, Wolfgang Iser, läsarens betydelse för tolkningen av litterära texter, ett program som först kallades receptionsestetik och senare reader-response criticism. Från att först ha varit avsändarorienterad, sedan fokuserad på själva det språkliga meddelandet, blev både språk- och litteraturvetenskap mer medvetna om mottagarens roll i den verbala kommunikationen.

På åtminstone en viktig punkt har dock utvecklingen av språk- respektive litteraturvetenskap inte följt parallella spår, nämligen vad beträffar textbegreppet. För även om det på senare år har börjat utvecklas vad som kallas för textlingvistik, med namn som Jean-Michel Adam, François Rastier och Dominique Maingueneau i spetsen, så är det få lingvistiska studier som behandlar texter av samma omfång och komplexitet som de litterära. För en litteraturvetare är det självklart att man också måste försöka förstå och tolka Prousts På spaning efter den tid som flytts tusentals sidor som en enda text; för en lingvist är en text som denna i stort sett obegriplig med de lingvistiska teorier och metoder som står till buds. De narratologiska analysverktyg som ingår i en litteraturvetares verktygslåda, från narratörer och fokalisationer till prolepser och frekvens, är irrelevanta för en satslingvistik.

I sin bok Fiction och diction tog Genette upp det besvärande faktum att texter normalt delas in i två huvudkategorier, litterär respektive icke-litterär text, och uttryckte sin förvåning över att den senare kategorin identifierades enbart i termer av vad den inte var. Orsaken till denna skevhet är dock inte svår att få ögonen på; det beror helt enkelt på att lingvistik inte har sysslat med texter i någon utpräglad grad. I dag vet vi väldigt mycket om litterära texter, men förhållandevis litet om andra texttyper. Bara för att ta ett exempel: i kommunikations- och kulturvetenskap, liksom i historia, talas det i dag mycket om the narrative turn, det vill säga att sanningen i många fall har ersatts av berättelser av olika slag för att vinna ett val eller att driva en politik. Men mig veterligen har lingvistik ännu inte studerat narrativer i någon högre grad; det har däremot litteraturvetenskap, som skulle ha mycket att erbjuda en lingvistik som vågade sig på att forska vidare bortom punkten.

En annan viktig skillnad mellan de två vetenskapsgrenarna är mer teoretisk. Vetenskap, menar många, bland dem Alan F. Chalmers, är till sin natur generaliserande; det finns ingen vetenskap som kan beskriva eller förklara enstaka och unika fall av något fenomen i verkligheten, vilket det än vara månde. Eller snarare: vetenskapen är i grunden ett försök att utifrån obser- 
vationer av enstaka fall, förhållanden eller objekt beskriva de generella lagar eller principer som observationerna faller under. Idiosynkrasier, exempelvis, är inte föremål för lingvistiska undersökningar. ${ }^{63}$

Detta är i och för sig inte kontroversiellt, men blir ett problem, om än inte för litteraturteori, så i varje fall för den delen av litteraturvetenskap som i andra länder än Sverige och Tyskland går under namnet litteraturkritik, nämligen ansträngningarna att försöka förstå vad det är som gör att Baudelaires Les fleurs du mal eller Becketts En attendant Godot till synes är unika, särpräglade och därmed exceptionella, dvs ett slags litterära idiosynkrasier. Sådana begrepp som "röst" eller "stil" används i litteraturkritik för att beteckna det som skiljer en författare från en annan, i motsats till det som författare och verk eventuellt har gemensamt med andra. Inom lingvistiken skulle det motsvara att man studerade enskilda individers språkbruk och försökte beskriva deras speciella egenheter, inklusive brister, men också kvaliteter, i förhållande till den gängse normen. Men det gör man alltså bara undantagsvis. Det är inte en tillfällighet att textlingvistik till största delen ägnar sig åt typologi, det vill säga att beskriva olika texttypers gemensamma drag i stället för vad som eventuellt skiljer dem åt.

Men kanske ska man inte överdriva den här teoretiska skiljelinjen. Trots allt - och detta har diskuterats livligt i litteraturteori - så måste man veta mycket om andra litterära texter för att kunna leda i bevis att en viss författare är unik eller egenartad. Hur ska man kunna visa eller bevisa att exempelvis Camus har en helt egen röst och stil, och vari den består, utan att känna till hur andra författare skriver? Hur ska man kunna hävda att Simenons användning av imperfektum skiljer sig från andra författares - vilket mycket tyder på att den gör -, om man inte har klart för sig hur imperfektum normalt används, i litteratur eller ej. Eller för att uttrycka det annorlunda: hur ska man veta om något är ett undantag från regeln om man inte vet vilken regeln är?

Den frågan har hittills inte riktigt tagits på allvar inom deskriptiv lingvistik, med visst undantag för sociolingvistik, även om man där främst studerar

63 Jean-Claude Milner (1995: 83), i sin Introduction à une science du langage, uttrycker det sålunda: "La linguistique néglige les cas où l'unité de variation est l'individu (variations individuelles) et retient seulement les cas où l'unité de variation est un groupe.". [Språkvetenskapen frånser de fall då variationsenheten utgörs av individen (individuella variationer) och tar endast i beaktande de fall då variationsenheten utgörs av en grupp.] (redaktörernas översättning). 
sociolekter, inte idiolekter. I själva verket skulle man kunna dra ytterligare en parallell mellan språk- och litteraturvetenskap genom att hävda att distinktionen mellan allmän eller systematisk lingvistik och tillämpad eller deskriptiv lingvistik motsvaras av distinktionen mellan litteraturteori - eller "poetik" i Todorovs bemärkelse - och litteraturkritik. Narratologi, exempelvis, är i grund och botten en generell teori om hur historier berättas på alla språk och i alla kulturer, på samma sätt som generativ teori är en generell teori om syntax, i alla språk. Genette, den moderna narratologins fader, har tydligt framhållit att narratologisk analys på intet sätt ger en uttömmande beskrivning eller förklaring av ett litterärt verk, typiskt romanen, i sin helhet; däremot har han hävdat att det enda som kan studeras "vetenskapligt" i litteratur är former, inte mening/innehåll. Parallellen kan till och med dras ännu längre. Somliga narratologer har hävdat att det finns en finit mängd olika sätt att berätta en historia, som i så fall måste antas grundade i medfödda kognitiva mönster, på samma sätt som generativ teori postulerar att det finns medfödda universella kognitiva syntaxstrukturer som går igen i alla språk.

Man kan lätt finna andra potentiella beröringspunkter mellan de två vetenskaperna. Exempelvis är det uppenbart att kunskaper om fonetik och fonologi är nödvändiga för varje filolog, inte bara för att edera texter, utan också för att tolka dem. En texttolkande litteraturvetare kan inte klara sig utan att ha ingående kunskaper i semantik och meningsbärande syntax, både i ett diakront och i ett synkront perspektiv. Litteraturvetenskapens genreteorier skulle ha mycket att vinna på att ta del av lingvistikens och språkfilosofins diskussion av kategoriseringsteorier, och vice versa. Det är egentligen anmärkningsvärt att man i litterär genreteori i stort sett aldrig stöter på Wittgensteins teori om familjelikheter eller de olika varianterna av prototypteori, som sannolikt skulle passa bra mycket bättre för att beskriva litterära genrers nebulosiska karaktär än Aristotelesinspirerade teorier i form av nödvändiga och tillräckliga egenskaper. Omvänt letar man förgäves i semantiska teorier och studier om kategorisering efter referenser till litteraturvetenskapens forskning i genrer. Något liknande gör sig gällande när det gäller de till synes oändliga diskussionerna om realism och naturalism i litteraturen; ingenstans finner man hänvisningar till det som går under namnet referentiell semantik, trots att det borde vara omedelbart relevant för att reda ut hur språkliga utsagor refererar till verkligheten ... eller till 
fiktiva referenter. Omvänt får man leta förgäves i den referentiella semantiken efter exempel från litteraturvetenskapens studier om realism och mimesis.

Det är naturligtvis inte möjligt att här föra en djupgående vetenskapsteoretisk diskussion om förhållandet mellan språk- och litteraturvetenskap. ${ }^{64}$ Däremot finns det anledning att fundera över varför de, trots uppenbara beröringspunkter teoretiskt och empiriskt, inte minst att båda studerar språkliga uttryck, tycks ha svårigheter att samarbeta och dra nytta av varandra. Man kan slå upp i stort sett vilken introduktion som helst till lingvistik, på alla möjliga språk, utan att finna något kapitel om det litterära språket. På sin höjd finner man i nyare introduktioner till lingvistik eller semantik ett kapitel om diskursanalys eller textlingvistik, men det är förgäves man söker efter litterära verk eller teorier som ett led i diskussionerna. Bara för att ta ett exempel: i Paveau och Sarfatis omfattande Les grandes théories de la linguistique (2003) ägnas mindre än en tiondedel åt "Les linguistiques discursives" utan en enda referens till någon litterarteoretiker. Man kan också förundras över - eller beklaga - att textsemantik inte har en större plats i introduktioner till ... semantik. Av fyra standardintroduktioner till semantik på franska (Tamba-Mecz 1998; Touratier 2004; Nyckees 1998; Baylon \& Mignot 2005) är det bara en som har ett kapitel om texters strukturer och betydelse, återigen utan att namn som Genette, Todorov, Booth, Hamon eller andra betydande textteoretiker nämns vid namn. Man - jag - kan också förvånas över att det i Bengt Sigurds och Gisela Håkanssons bok Språk, språkinlärning \& språkforskning (2007), två kloka och bevisligen open-minded lingvister, inte finns något kapitel om semantik, dvs om studiet av mening och betydelse, trots att det är omöjligt att studera språk utan att behärska och förstå det språk man studerar. Det är också förgäves man letar efter hänvisningar till litteraturvetare och litteraturteoretiker i verk om kognitiv lingvistik och semantik. När man som littteraturvetare läser den numera klassiska Lakoffs och Johnsons Metaphors we live by från 1980 kan man ofta få intrycket av att de båda författarna uppfinner hjulet på nytt. I Jean-Claude Milners fullmatade Introduction à une science du langage (1995)

64 För att undvika missförstånd vill jag understryka att de tendenser och strömningar jag ytterst kortfattat beskriver här är generaliseringar och att det naturligtvis finns undantag bland enskilda forskare och skillnader mellan olika länders forskningstraditioner. 
finns ett helt kapitel om språkvetenskapens relation till "andra vetenskaper"; litteraturvetenskap nämns inte där med ett ord.

Det omvända förhållandet gäller varje verk om litteraturteori; begrepp hämtade från språkvetenskap och språkfilosofi finns det gott om, men man stöter aldrig på någon ingående diskussion om grundläggande semantik eller pragmatik, som borde vara en självklar grund att stå på för varje försök att förstå och tolka språk, litterärt eller ej.

Ett av få försök att på allvar föra de två vetenskaperna närmare varandra är Ducrots och Todorovs Dictionnaire encyclopédique des sciences du langage (1972), som 1995 kom ut i en betydligt reviderad upplaga under titeln Nouveau dictionnaire encyclopédique des sciences du langage, med Jean-Marie Schaeffer som medförfattare till Ducrot i stället för Todorov. I den reviderade upplagan skriver Ducrot och Schaeffer:

Toute tentative d'isoler l'étude de la langue de celle du discours se révèle, tôt ou tard, néfaste à l'une et à l'autre. En les rapprochant, nous ne faisons d'ailleurs que renouer avec une longue tradition, celle de la philologie, qui ne concevait pas la description d'une langue sans une description des œuvres. (1995: 8)

[Varje försök att isolera studiet av språket från studiet av diskursen kommer förr eller senare att visa sig vara katastrofal för dem båda. Genom att låta språkstudiet och studiet av diskursen närma sig varandra gör vi för övrigt inget annat än att återknyta till en lång tradition, nämligen filologins, som inte uppfattade att språk kunde beskrivas utan att också dess litterära verk beskrevs. $]^{65}$

Vidare:

Notamment l'analyse linguistique se priverait d'une justification essentielle, si elle se refusait de servir à l'analyse littéraire. Quant à une étude de la littérature qui prétendrait faire l'impasse sur la nature verbale des œuvres, elle perdrait toute légitimité et se réduirait à juxtaposer les unes aux autres différentes lectures d'un même texte. (1995: 10)

[Särskilt den språkvetenskapliga analysen skulle berövas ett väsentligt självberättigande, om den inte användes för litteraturanalys. En litteraturvetenskap som å sin sida skulle hävda att den kunde förbise verkens språk-

65 Redaktörernas översättning. 
liga sida skulle förlora all legitimitet och reduceras till en samling skilda läsningar av en och samma text.] $]^{66}$

Även om detta snarast är att uppfatta som ett slags programförklaring, som kräver preciseringar, så skulle förmodligen många eller flera hålla med ... i princip. Verkligheten ser dock annorlunda ut. Som redan nämnts är studiet av det nationella språket på universitetet i regel skilt från studiet av dess litteratur. ${ }^{67}$ Exemplen på gemensamma forskningsprojekt mellan allmän lingvistik eller nordiska språk respektive litteraturvetenskap är försvinnande få. I Lund fördes under många år en diskussion om att införa en gemensam introduktionskurs i grundläggande språkvetenskap för alla studenter i främmande språk och svenska som skulle ersätta de kurser som gavs inom respektive ämne. Förslaget fick kalla handen, såväl av litteraturvetare som av språkvetare inom språkämnena. Varför? Därför att kursen skulle hållas av allmänlingvister. Men även inom språkämnena själva, inklusive de romanska, har det varit tunnsått med konkreta samarbeten, både forskningsmässigt och pedagogiskt. På RI i Lund har visserligen de litterära forskarstuderande en introduktionskurs i lingvistik med tyngdpunkt på semantik, men det omvända gäller inte inom den lingvistiska inriktningen. På sin höjd läser de språkvetenskapliga doktoranderna och masterstudenterna ett antal litterära verk, som ett slags litteraturhistorisk bildning, men utan att de fått metodiska verktyg att behandla verken med vetenskapliga pretentioner.

Men varför är det så? Behöver det vara så? Borde det vara så? Vill "vi" att det ska vara så?

Det vore naturligtvis förmätet att uttala sig om hur språk- och litteraturvetenskapliga kolleger borde bedriva sin vetenskap. Icke desto mindre är jag övertygad om att språk- och litteraturvetenskap har mycket att vinna på att samarbeta och dela kunskaper och metodik. Vinsterna av ett närmare samarbete kommer dock inte per automatik. Det skulle kräva att både lingvister och litteraturvetare i högre grad började reflektera över vad det är som förenar dem snarare än vad som skiljer dem åt.

Ett första steg vore att både lingvister och litteraturvetare gjorde upp med en förutfattad uppfattning om relationen mellan å ena sidan tal- och skriftspråket, och, å den andra, mellan skriftspråk i allmänhet och det litte-

66 Redaktörernas översättning.

67 Men inte i Danmark där litteratur i första hand studeras inom ämnet Nordiska språk. 
rära språket. För det första finns det, som redan nämnts, en ganska utbredd uppfattning bland många - men inte alla - lingvister att skriftspråket inte bara är ett språk som historiskt uppstått ur talspråket, utan också och mer radikalt att skriftspråket är en "kopia" av talspråket, underförstått att skriftspråket inte är ett prioriterat forskningsobjekt för lingvistik.

För det andra finner man både bland många lingvister och litteraturvetare en uppfattning att det litterära och poetiska språket är ett särskilt språk, som följer radikalt andra regler än det så kallade "naturliga" och spontana språket. De forskare som på allvar tagit itu med frågan om det litterära språkets särprägel, dess "litteraritet" - man kan nämna Gregory Currie, John Searle, Käte Hamburger, Anne Reboul - är dock av den bestämda uppfattningen att skillnaden mellan litterärt och icke-litterärt språk på sin höjd är en gradskillnad, som enbart - och inte ens det är säkert - visar sig på ett visst begränsat antal punkter, varav de flesta på textnivå. Varje gång någon har påstått sig finna språkliga egenheter - exempelvis vissa figures de style eller typer av metaforer - som bara skulle finnas i den ena eller den andra språktypen, har någon annan snart kunnat visa att samma fenomen också uppträder i annat språk. Det som skiljer talat språk från skriftligt är sällan grundläggande grammatik eller semantik, utan det faktum att skriftspråk, inklusive det litterära, är exempel på "uppskjuten kommunikation”, communication différée, det vill säga en talsituation där interlokutörerna inte är i omedelbar kontakt med varandra och därför inte kan lösa förståelse- och tolkningsproblem på ort och ställe.

Det anmärkningsvärda i sammanhanget är att somliga lingvister $p a ̊$ för hand, utan vetenskaplig granskning, tycks utesluta vissa språkliga uttryck bland andra som rättmätiga föremål för lingvistisk forskning, alldeles bortsett ifrån att man kan sätta frågetecken vid själva föreställningen om att det skulle existera ett så kallat "naturligt" talspråk som var gemensamt för alla lokutörer av ett givet språk. I själva verket kan uppfattningen att det spontana talspråket är ett mer "autentiskt" eller "naturligt" språk än annat språk knappast betraktas som annat än en - ganska ovetenskaplig - hypotes. 
En andra stötesten för ett mer fruktbart utbyte av metodik och kunskap mellan de två grenarna är lingvistikens relativa ointresse för vad man skulle kunna kalla för deskriptiv eller empirisk semantik, det vill säga en systematisk studie av ords, satsers och texters betydelse, både diakroniskt och synkroniskt, till skillnad från deras struktur och grammatik. Det saknas naturligtvis inte semantiska studier inom lingvistik, men kvarstår gör att tyngdpunkten inom lingvistik ligger på de mer systematiska delarna av språket, i synnerhet syntaxen. De områden som är mer "röriga", föränderliga och som uppvisar en lägre grad av intersubjektivitet lämnas gärna därhän. Bara för att ta ett exempel, så är det få av de ord som uppträder i de stora ordböckerna, om det så är Littré eller Le Robert, som varit föremål för ingående semantisk forskning; i allt väsentligt är definitioner och anmärkningar om register baserade på redaktörernas språkliga intuition. All lingvistisk analys bygger i själva verket på en förförståelse av språklig mening; det går inte att studera ett språk som man inte "talar". Man skulle därför tro att mening och förståelse borde stå i centrum av språkvetenskap, i all synnerhet med tanke på att språket är ett verktyg för att kommunicera mening, inte för att förmedla språkliga strukturer. Själva vitsen med språkets "dubbla artikulation", dvs att man utnyttjar icke meningsbärande enheter för att bygga språkliga uttryck, är ju att producera och kommunicera mening. En språkvetenskap som ägnar alltför stor uppmärksamhet åt de icke meningsbärande byggstenarna missar själva poängen med språket, på samma sätt som en litteraturvetenskap som bara studerar former och strukturer missar poängen med vad litteratur är och vad den är till för. Eller för att säga det mer provokativt: man kan inte kommunicera med syntax enbart!

\section{$\cos$}

Ett tredje problem har att göra med vad man skulle kunna kalla för språkets normativa sida, le bon usage eller "språkriktighet" i språkvetenskap och frågan om "litterär kvalitet" eller "estetik" inom litteraturvetenskap. De flesta språkoch litteraturvetare skulle säkert hävda att man vetenskapligt visserligen kan studera normer och värderingar, men att man inte som forskare ska ta ställning till frågan om vad som är bra och dåligt. Vetenskap är ju och bör vara värdeneutral; den bör sträva mot objektivitet. 
Det är förmodligen inte överdrivet att hävda att litteraturvetenskap har haft större svårigheter än lingvistik att förhålla sig till frågan om kvalitet; varje beslut om vilka litterära texter som skall beforskas eller undervisas i är till syvende och sist också ett beslut om vilka texter som i någon mening är värda att uppmärksammas. Jag minns en disputation i engelsk litteratur då en avhandling om den erotiska romanen Fanny Hill skulle försvaras. Betygskommittén, av vilken jag var en del, var rörande enig om att avhandlingen var utmärkt och att den skulle godkännas. När förhandlingarna var över och betyget beslutat bad emellertid opponenten, en professor från Yale, om ordet och ställde försynt frågan om det trots allt inte var synd att disputanden hade ägnat fyra år av sitt kreativa vetenskapliga liv åt att studera en roman som i själva verket var ganska ointressant, både estetiskt och innehållsligt! Det ligger ju också i själva begreppt "litteraturkritik" en tanke om selektion och urval; man kan påminna om att man varken i Frankrike eller den anglosaxiska världen använder termen "litteraturvetenskap", utan just critique littéraire eller literary criticism. Det ligger en viss ironi i att Terry Eagleton, efter att ha deklarerat såväl litteraturteorins som litteraturens "död" i sin bok Literary Theory därefter skrev en volym om ... Shakespeare!

I jämförelse kan det i förstone se ut som om lingvistiken går fri från misstankar om att ägna sig åt ljusskygga normativa aktiviteter; man studerar ju språket som det är utan att ta ställning till hur det borde vara eller vilka former av språk som i någon mening är bättre än andra. Som jag har försökt visa i diverse sammanhang kan emellertid lingvistiken bara upprätthålla sin objektiverande vetenskaplighet genom ett epistemologiskt felslut, nämligen att språket, och i synnerhet meningen, dvs semantiken, på något sätt skulle ha en objektiv existens som kan studeras genom ett tredjepersonsperspektiv. I själva verket är meningsbärande språk intersubjektivt till sin karaktär och kan bara studeras genom det som i etnologi och antropologi kallas för deltagande observation. Det skulle föra för långt här att upprepa ganska invecklade resonemang och argument som jag fört fram i andra skrifter, men även lingvister, i varje fall de som undervisar i språk, måste trots allt ta ställning till vilket språk det är som ska uppmuntras - eller sanktioneras - i undervisning och examination. Man kan inte slingra sig undan frågan om vilken typ av språkbruk det är som ska anses vara det "riktiga" eller det "bästa" med argumentet att man ska lära ut det "naturliga" språket. För vems 
"naturliga språk" är det som avses? I Italien är det numera få som kan använda konjunktiven korrekt; ska vi därför eller ska vi inte lära ut konjunktiven till våra studenter? Fransmän i gemen använder numera konjunktiv efter après que, vilket enligt grammatikerna är oegentligt; vad ska vi välja att lära ut? Med andra ord måste även en inbiten språkvetare bestämma sig för vilket språk och vilka språkregister som ska tjäna som förebild, inte bara för våra studenter, utan också för oss själva. Vi gör det redan utan att blinka när vi handleder uppsatser och kräver tydlighet och precision. Varför skulle vi inte resonera på samma sätt när det gäller vardagligt och annat språk? Med andra ord: varför ska man över huvud taget lära ut och forska i språk om det inte också är för att bidra till att förbättra kvaliteten på den verbala kommunikationen människor emellan? Ingen skulle väl komma på tanken att anklaga medicinsk forskning för bristande vetenskaplighet därför att det övergripande målet är att förbättra människors hälsa?

Det är på denna punkt, det vill säga språkvetenskapens möjliga bidrag till en bättre språklig kommunikation människor emellan, som litteraturen, inte bara som litteratur utan också som språk, har en viktig roll att spela. En av de viktiga funktioner som de ryska formalisterna tillskrev det litterära och poetiska språket var att "avfamiljarisera" det vardagliga språket, ofta fullt av intetsägande klichéer, fossiliserade uttryck, vilseledande metaforer och luddig satslogik. Det finns naturligtvis stereotyp och språkligt torftig litteratur som ibland, tyvärr, passerar förlagens kvalitetsgranskning, men det är ett kriterium på litterär kvalitet att språket gnistrar och sprakar, inte minst därför att det just är fråga om en uppskjuten kommunikation utan en förutbestämd målgrupp med ett i förväg delat språk, vilket ställer högre krav på precision och tydlighet. Men inte bara det: en av den - goda - litteraturens, och kanske särskilt poesins, viktiga funktioner har till alla tider varit att bidra till att förnya och berika språket. Litteratur ska självklart undervisas och forskas i också som litteratur, men varför avhända sig möjligheten att använda - god - litteratur även som en språklig förebild? Det räcker med att studera de transkriptioner som görs i konversationsanalys av vardagligt språk för att inse att frågan är relevant. Eller, för den sakens skull, att lyssna på Trumps oskriptade tal eller läsa hans tweets!

För att antal år sedan organiserade doktoranderna i Lund en konferens för alla romanska doktorander i Sverige. Uppslutningen var god och dis- 
kussionerna livliga. Som talare hade man även bjudit in två forskare och handledare i form av professor Suzanne Schlyter och undertecknad. Det väckte en viss uppmärksamhet - och munterhet - när jag deklarerade att den enda väsentliga skillnaden mellan språk- och litteraturvetenskap var att litteraturvetare studerade bättre texter. Uttalandet var naturligtvis delvis avsett att skapa debatt, vilket det gjorde, men det var också allvarligt menat. För frågan kvarstår i stort sett ograverat: vilken typ av språk ska vi förorda och hålla upp som förebild för våra studenter? Och för oss själva?

\section{es}

Det finns naturligtvis flera rimliga invändningar mot det resonemang jag fört här, även om man i stora drag delar tesen att språk- och litteraturvetenskap skulle ha mycket att vinna på ett närmare samarbete. En av dem vore förstås att forskning är internationell och har mycket litet att göra med hur just romanska språk institutionellt och informellt bedrivs i ett land som Sverige. En forskare eller forskarstuderande i antingen språk eller litteratur som vill dra fördel av respektive vetenskaps landvinningar är ju inte beroende av sina närmaste kolleger på sitt eget universitet eller i sitt eget land, utan har världen som arbetsfält. Invändningen är i sig försvarbar, men då glömmer man att vi inom romanska språk normalt arbetar inom små miljöer som ytterligare försvagas om vi låter dem fragmenteras i olika specialiseringar, både i forskning och på grundutbildningen.

En annan invändning är att forskarutbildningen måste ägnas fullt ut åt den ena eller den andra inriktningen för att leda fram till avhandlingar av internationellt gångbar kvalitet. Detta äger sin riktighet, men en universitetslärares och forskares gärning upphör inte med avhandlingen. Man kan faktiskt vidareutbilda sig under hela sitt yrkesliv, i synnerhet om man har gemensamma seminarier och överlag försöker finna de områden där ett ömsesidigt utbyte gagnar även den egna vetenskapen och specialiseringen. Det är ett vetenskapshistoriskt faktum att de flesta viktiga framsteg inom vetenskapen har uppstått i gränslandet mellan olika vetenskaper. Man kan också lära sig ytterligare ett eller två romanska språk utöver det primära om man lägger manken till. Men för det krävs, med Harry Martinsons ord, fast i ett annat sammanhang, god vilja, god vilja och åter god vilja. 
Min förhoppning vore att den funnes, både när det gäller romanska språk respektive språk- och litteraturvetenskap.

\section{Bibliografi}

Adam, Jean-Michel, 1990: Éléments de linguistique textuelle. Liège: Éditions Mardaga.

Baylon, Christian \& Mignot, Xavier, 2005: Initiation à la sémantique du langage. Paris: Armand Colin.

Camproux, Charles, 1974: Les langues romanes. Paris: PUF : Que sais-je?.

Currie, Gregory, 1990: The Nature of Fiction. Cambridge: Cambridge University Press.

Ducrot, Oswald \& Todorov, Tzvetan, 1972: Dictionnaire encyclopédique des sciences du langage. Paris: Le Seuil.

Ducrot, Oswald. \& Schaeffer, Jean-Marie, 1995: Nouveau dictionnaire encyclopédique des sciences du langage. Paris: Le Seuil.

Eagleton, Terry, 1996 [1983]: Literary Theory. University of Minnesota Press.

Genette, Gérard, 1991: Fiction et diction. Paris: Le Seuil.

Hamburger, Käte, 1993: The Logic of Literature. Indiana University Press.

Lakoff, George \& Johnson, Mark, 1980, 2003: Metaphors We Live By. Chicago: The University of Chicago Press.

Larsson, Björn

- 1996: Le Bon sens commun. Remarques sur le rôle de la (re)cognition intersubjective dans l'épistémologie et l'ontologie du sens. Lund: Lund University Press, Études Romanes de Lund.

- 2008: Le sens commun ou la sémantique comme science de l'intersubjectivité humain. I: Langages 170, juin. 28-40.

- 2012: La sémantique, une science humaniste? Extrapolations à partir de Georges Kleiber, I: Saussure, Louis de, Borillo, Andrée \& Vuillaume, Marcel (red.), Grammaire, lexique, référence. Mélanges offertes à Georges Kleiber pour ses quarante ans de carrière, Bern etc: Peter Lang. 409-423.

Maingueneau, Dominique, 2004: Le discours littéraire. Paris: Armand Colin.

Milner, Jean-Claude, 1995 [1989]: Introduction à une science du langage. Paris: Le Seuil.

Nyckees, Vincent, 1998: La sémantique. Paris: Belin.

Paveau, Marie-Anne \& Sarfati, Georges-Élia, 2003: Les grandes théories de la linguistique, Paris: Armand Colin.

Reboul, Anne, 1992: Rhétorique et stylistique de la fiction. Nancy: Presses universitaires de Nancy. 
Searle, John, 1974-75: The Logical Status of Fictional Discourse. I: New Literary History 6. 319-32.

Sigurd, Bengt \& Håkansson, Gisela, 2007: Språk, språkinlärning \& språkforskning. Lund: Studentlitteratur.

Tamba-Mecz, Irène, 1991: La sémantique. Paris: PUF, Que sais-je?.

Touratier, Christian, 2004: La sémantique. Paris: Armand Colin.

Översikt över publicerade avhandlingar och monografier i romanska språkens skriftserier i Göteborg, Lund, Stockholm och Uppsala.

Anm. Avhandlingar i romanska språk, särskilt under senare decennier, har också lagts fram vid andra universitet, främst Umeå och Växjö. Jag har inte systematiskt inventerat dessa, men kunnat konstatera att de bara marginellt skulle ha påverkat fördelningen mellan de olika romanska språken, liksom fördelningen mellan språk- och litteraturvetenskap.

\section{Totalt vid alla fyra universitet}

Litteraturvetenskap

- franska 75

- italienska 14 (varav samtliga utom en i Stockholm)

- $\quad$ spanska 17

Språkvetenskap

- franska 124

- $\quad$ italienska 23

- rumänska 2

- $\quad$ spanska 23

Filologi

- fransk 41

- $\quad$ italiensk 3

- $\quad$ spansk 3

Romanska spràk

- $\quad$ språkvetenskap 3 


\section{Göteborg}

Romanica Gothoburgensia 1955-2014 (nr I-LXX)

\section{Franska}

- filologi 8

- litteratur 12

- $\quad$ språk 28

Italienska

- filologi 3

- litteratur

- $\quad$ språk 5

Spanska

- filologi

- litteratur 4

- $\quad$ språk 5

\section{Lund}

Études romanes de Lund 1940-2015 (nr 1-102)

Franska

- filologi 16

- litteratur 21

- $\quad$ språk 31

Italienska

- filologi

- litteratur 1

- språk 10

\section{Rumänska}

- $\quad$ språk 2

Spanska

- filologi

- litteratur 6

- $\quad$ språk 4 


\section{Stockholm}

Forskningsrapporter 1994-2016 (nr 1-56)

Romanica Stockholmiensia 1964-2013 (nr 1-30)

Franska

- filologi 9

- $\quad$ litteratur 21

- $\quad$ språk 27

Italienska

- filologi

- litteratur 13

- $\quad$ språk 9

Spanska

- filologi 2

- litteratur 3

- $\quad$ språk 3

\section{Uppsala}

Studia Romanica Upsaliensia 1961-2007 (nr 1-2007)

Franska

- filologi 8

- litteratur 21

- $\quad$ språk 38

Italienska

- filologi

- litteratur

- $\quad$ språk 2

Spanska

- filologi 1

- litteratur 1

- $\quad$ språk 8

Romanska språk

- $\quad$ språk 3 